\title{
Gene expression study using real-time PCR identifies an NTR gene as a major marker of resistance to benznidazole in Trypanosoma cruzi
}

\author{
Ana M Mejía-Jaramillo, Geysson J Fernández, Lina Palacio and Omar Triana-Chávez
}

\begin{abstract}
Background: Chagas disease is a neglected illness, with limited treatments, caused by the parasite Trypanosoma cruzi. Two drugs are prescribed to treat the disease, nifurtimox and benznidazole, which have been previously reported to have limited efficacy and the appearance of resistance by T. cruzi. Acquisition of drug-resistant phenotypes is a complex physiological process based on single or multiple changes of the genes involved, probably in its mechanisms of action.

Results: The differential genes expression of a sensitive Trypanosoma cruzi strain and its induced in vitro benznidazole-resistant phenotypes was studied. The stepwise increasing concentration of BZ in the parental strain generated five different resistant populations assessed by the $\mathrm{I}_{50}$ ranging from 10.49 to $93.7 \mu \mathrm{M}$. The resistant populations maintained their phenotype when the BZ was depleted from the culture for many passages. Additionally, the benznidazole-resistant phenotypes presented a cross-resistance to nifurtimox but not to G418 sulfate. On the other hand, four of the five phenotypes resistant to different concentrations of drugs had different expression levels for the 12 genes evaluated by real-time PCR. However, in the most resistant phenotype (TcR5x), the levels of mRNA from these 12 genes and seven more were similar to the parental strain but not for NTR and OYE genes, which were down-regulated and over-expressed, respectively. The number of copies for these two genes was evaluated for the parental strain and the TCR5x phenotype, revealing that the NTR gene had lost a copy in this last phenotype. No changes were found in the enzyme activity of CPR and SOD in the most resistant population. Finally, there was no variability of genetic profiles among all the parasite populations evaluated by performing low-stringency single-specific primer PCR (LSSP-PCR) and random amplified polymorphic DNA RAPD techniques, indicating that no clonal selection or drastic genetic changes had occurred for the exposure to BZ.

Conclusion: Here, we propose NTR as the major marker of the appearance of resistance to BZ.
\end{abstract}

\section{Background}

American trypanosomiasis, or Chagas disease, is a neglected parasitic illness widely spread throughout the Americas, from the Southern United States to Argentina and Chile. Trypanosoma cruzi currently infects at least $7,694,500$ individuals and between 60 and 80 million remain at risk of $T$. cruzi infection in endemic countries $[1,2]$. There is no vaccine to prevent the infection and chemotherapy is restricted to two nitroheterocyclic compounds: nifurtimox (NFX (4[(5-nitrofurfurylidene) amino]-3-methylthiomorpholine-1,1-dioxide) and

\footnotetext{
* Correspondence: omar.triana@siu.udea.edu.co

Grupo Biología y Control de Enfermedades Infecciosas-BCEI-SIU, Instituto de Biología, Universidad de Antioquia, Medellín, Colombia
}

benznidazole (BZ (N-benzyl-2-nitroimidazole-1-acetamide) $[3,4]$.

$\mathrm{BZ}$ is a nitroheterocyclic compound that contains a nitro group linked to an imidazole ring. As a pro-drug, $\mathrm{BZ}$ undergoes activation by enzymatic activity to have cytotoxic effects within the parasite, which is catalyzed by nitroreductases (NTRs) [5]. Because there are two possible enzymes acting on it, there are two proposed hypotheses for its toxic action. The first one postulates the generation of reactive oxygen species (ROS) following a one-electron reduction caused by NTR type II enzymatic activity. Under aerobic conditions, this induces the production of superoxide anions and causes re-cycling of the drug [6]. However, it is now known

\section{Biomed Central}


that $T$. cruzi possesses both enzymatic and non-enzymatic antioxidant defenses, making it unlikely that ROS production affects the viability of the parasite, at least at the doses used to treat the disease [7-11]. The second hypothesis proposes a two-electron reduction of the drug by NTR type I. This reaction goes through a nitroso species, to a hydroxylamine derivative using $\mathrm{NADPH}$ as a source of electron donors. Hydroxylamine can react to produce a nitrenium cation, which induces DNA strand breaks. Moreover, the high electrophilic intermediaries may affect other molecules within the cell [12]. There are two trypanosomal enzymes with this type of activity: prostaglandin F2 $\alpha$ synthase or old yellow enzyme (OYE), which mediates two-electron reduction in NFX under anaerobic conditions [13] and nitroreductase I (NTR). This second enzyme has already shown strong experimental evidence associated with cross-resistance to NFX and BZ $[5,12,14,15]$. Despite the great efforts made to understand BZ's mode of action, it is not yet completely clear; even less thoroughly studied are the initially acquired mechanisms of resistance.

Acquisition of drug-resistant phenotypes is a complex physiological process based on single or multiple changes of genes involved in its mechanisms of action [16-18]. Many studies have been based on differential gene expression analysis in high concentrations of $\mathrm{BZ}$ in resistant phenotypes [19-26], but the commencement of this condition remains to be understood. For this reason, the identification of genes that are differentially expressed during progression through the susceptible drug population to a resistant phenotype in T. cruzi populations may help to further our grasp of acquired stable resistance mechanisms, including the basis of the drug's mode of action. Additionally, it is also important to identify gene expression and/or genetic alterations as markers of either sensitivity or resistance responses, which could be useful for treatment prognosis and as potential new therapeutic targets. Therefore, the aim of this study was to examine the initial expression changes of parasites submitted to a stepwise concentration of BZ. For this reason, we chose 19 genes suggested to be involved in escaping BZ cytotoxic effects. Their RNA expression was quantified by real-time PCR (RT-qPCR). We also investigated other issues concerning drug resistance, such as the stability of BZ-resistant phenotypes without drug pressure over a long period of time as well as the cross-resistance with other nitroheterocyclic and non-nitroheterocyclic drugs.

\section{Materials and methods Reagents}

BZ and NFX were purified by organic extraction from Rochagan $^{\mathrm{TM}}$ tablets (Roche, Brazil) and Lampit ${ }^{\circledR}$ (Bayer, El Salvador), respectively. Stock solutions were dissolved in $100 \%$ dimethyl sulfoxide (DMSO) at a final concentration of $10 \mathrm{mM}$. G418 sulfate was purchased from AMRESCO and diluted in sterile water to a final concentration of $50 \mathrm{mg} / \mathrm{ml}$.

\section{Parasite cultures}

T. cruzi epimastigotes were cultured in liver infusion tryptose (LIT) medium supplemented with $10 \%(\mathrm{v} / \mathrm{v})$ heat-inactivated fetal bovine serum (FBS) at $28^{\circ} \mathrm{C}$. Cultures were maintained in exponential growth by passages every 7 days [27].

\section{In vitro induction of BZ-resistant in $T$. cruzi parasites}

In vitro resistance to $\mathrm{BZ}$ was induced in the susceptible discrete typing unit (DTU) I strain M.RATTUS/CO/91/ GAL-61.SUC (named Gal61) using $3 \times 10^{7}$ epimastigotes in the logarithmic growth phase. The parasites were exposed to stepwise concentrations of BZ beginning with its initial inhibitory concentration of $50 \%$ $\left(\mathrm{IC}_{50}\right)$ (see Results). After this procedure, resistant parasites at different concentrations were obtained until reaching a resistant population at BZ $50 \mu \mathrm{M}$, which corresponds to the concentration of $\mathrm{BZ}$ in plasma during a chemotherapy course in humans $[19,28]$.

\section{MTT assays}

$\mathrm{IC}_{50}$ of BZ, NFX and G418 in the different phenotypes was determined using an enzymatic micromethod 3(4,5-dimethylthiazol-2-yl)-2,5-diphenyltetrazolium bromide (MTT) per triplicate in two independent experiments [29]. T. cruzi epimastigotes were seeded in 96well plates (Falcon, Ref. 353072) at $1 \times 10^{7} \mathrm{ml}^{-1}$ in 200 $\mu \mathrm{l}$ of growth medium containing different concentrations of BZ, NFX or G418. After incubation at $28^{\circ} \mathrm{C}$ for 96 hours, $10 \mu \mathrm{l}$ of MTT/PMS (Sigma, USA) was added to each well and the plates incubated again for $90 \mathrm{~min}$ more. Cell density was determined by monitoring the reduction of MTT to formazan crystals at $595 \mathrm{~nm}$ in an enzyme-linked immunosorbent assay (ELISA) reader (Bio-Rad). The drug concentration that inhibits parasite growth by $50 \%\left(\mathrm{IC}_{50}\right)$ was calculated by a dose-response curve using non-linear regression analysis carried out with Prism 5.0 Software (GraphPad, San Diego, CA, USA). Finally, the resistant $T$. cruzi populations were sub-cultured without BZ for 3 months and then the $\mathrm{IC}_{50}$ was determined as described above with the aim of quantifying the stability in BZ-resistant phenotypes.

\section{Study of gene expression in phenotypes resistant to different concentrations of $\mathrm{BZ}$}

To evaluate the genetic expression in the different phenotypes, we looked for reported genes in drug response in a variety of kinetoplastids including Leishmania spp., Plasmodium spp., T. brucei and T. cruzi. Afterward, the 
selected genes were considered potential markers of resistance and grouped together according to their function (Table 1).

DNA and RNA preparations of T. cruzi

Genomic DNA and total RNA were isolated using the GeneJET TM Purification Kits (Fermentas, USA) as described by the manufacturers. DNA and RNA integrity was analyzed by electrophoresis in $1 \%$ agarose gels in $1 \times$ TBE ( $89 \mathrm{mM}$ Tris borate, $2 \mathrm{mM}$ EDTA [pH 8.3]), stained with ethidium bromide and visualized under UV light. Nucleic acid was quantified measuring the absorbance at $260 \mathrm{~nm}$ using nanodrop technology. Nucleic acid purity was assessed quantifying the A260 nm/ A280-nm ratio (acceptable when the ratio was $>1.8$ ).

\section{cDNA preparations}

A total of $10 \mu \mathrm{g}$ total RNA was treated with $1 \mathrm{U}$ DNase I (Promega) for $2 \mathrm{~h}$ at $37^{\circ} \mathrm{C}$ and then heat-inactivated at $65^{\circ} \mathrm{C}$ for $10 \mathrm{~min}$ before reverse transcription to eliminate genomic DNA (gDNA) contamination. For first-strand cDNA synthesis, the reverse transcription reaction contained $2 \mu \mathrm{g}$ of treated RNA, $50 \mu \mathrm{M}$ oligo $\mathrm{d}(\mathrm{T}), 500 \mathrm{ng} /$ $\mu \mathrm{l}$ hexamer primer, $5 \times$ buffer, $10 \mathrm{mM}$ dNTP, 1 U Revert Aid M-MLV (Fermentas) reverse transcriptase in a final volume of $20 \mu \mathrm{l}$. The mixture was incubated at $42^{\circ} \mathrm{C}$ for

Table 1 Sequences of primers used to amplified T.cruzi genes using qPCR

\begin{tabular}{|c|c|c|c|c|}
\hline Function & Genes/Genebank ID & Size & Forward & Reverse \\
\hline \multirow[t]{3}{*}{ Activation system } & Old Yellow enzyme (OYE) $1 /$ AB075599 & $\begin{array}{l}146 \\
b p\end{array}$ & 5'-ACTITCGCTTGCCTATCTGC-3' & 5'-GTATTTGCTGGTCTGCCTCTTC-3' \\
\hline & Nitroreductase I (NTR) $)^{1} /$ XM805552 & $\begin{array}{l}195 \\
b p\end{array}$ & 5'-GCACGTGATTGGTATGGATG-3' & 5'-CITGTTGGGTCAAATCGCT-3' \\
\hline & $\begin{array}{c}\text { NADPH-cytochrome P450 reductase } \\
(\text { P450) })^{1 / D Q 857724}\end{array}$ & $\begin{array}{l}140 \\
b p\end{array}$ & 5'-GCATACCGGTTGGACACTTT-3' & 5'-GCCTTCAGGAATGATACGGA-3' \\
\hline \multirow[t]{6}{*}{$\begin{array}{l}\text { Detoxification system } \\
\text { of free radicals }\end{array}$} & Trypanothione reductase $(\mathrm{TRYT})^{1} / \mathrm{M} 38051$ & $\begin{array}{l}191 \\
b p\end{array}$ & 5'-CTCTACAAGAAGCGGGTTGC-3' & 5'-CTGAGAGTGGTGCGATCAAA -3' \\
\hline & $\begin{array}{l}\text { Glutathionyl spermidine synthetase (GTS) } \\
\text { 1/XM_815753.1 }\end{array}$ & $\begin{array}{l}125 \\
b p\end{array}$ & 5'-ACTTCCACCGGGTCTाTCT-3' & 5'-CTGCGGCATTCATCACATAC -3' \\
\hline & $\begin{array}{l}\text { Trypanothione synthetase (TS) }{ }^{1} / \\
\text { XM_805507.1 }\end{array}$ & $\begin{array}{l}130 \\
b p\end{array}$ & 5'-ATCCGTTGGAGGATGAAGTG-3' & 5'-TAAATGTCAGACGACGCAGC-3' \\
\hline & $\begin{array}{l}\text { Cytosolic tryparedoxin peroxidase }(\mathrm{CTXP})^{2} / \\
\text { AJ012101 }\end{array}$ & $\begin{array}{l}169 \\
b p\end{array}$ & 5'-AAGTGGCTGGTGCTCTTCTT-3' & 5'-TTGCGCTCAATGCTTGTCCA-3' \\
\hline & $\begin{array}{l}\text { Mitochondrial tryparedoxin peroxidase } \\
(\text { (mTXP) } / \text { AJ006226.1 }\end{array}$ & $\begin{array}{l}137 \\
b p\end{array}$ & 5'-TGCAACACCCTGCGACTTCTTA-3' & 5'-GCCCTTGTAGTCATTCAAGCTG-3' \\
\hline & Superoxide dismutase-A (SOD) 1 /U90722 & $\begin{array}{l}184 \\
b p\end{array}$ & 5'-GTTGAGACGTGCGGTGAATA-3' & 5'-GCCTTGTGGTGTTGGTGTA-3' \\
\hline $\begin{array}{l}\text { Extracellular flow of } \\
\text { drugs system }\end{array}$ & $\begin{array}{l}\text { Multi-drug resistant gene }(M D R)^{1} / \\
\text { XM_806226.1 }\end{array}$ & $\begin{array}{l}188 \\
b p\end{array}$ & 5'-ATCGCTTCTATGACCCTTCCTC-3' & 5'-GGCTTCCTCCACTTCTTCGT-3' \\
\hline \multirow[t]{4}{*}{$\begin{array}{c}\text { Folate metabolism } \\
\text { system }\end{array}$} & pteridine reductase-1 (ptr1)¹/AF174398 & $\begin{array}{l}157 \\
b p\end{array}$ & 5'-ACAGTATCGCTGTGCGTCTG-3' & 5'-AGAGAGCTGCCGAGACTGAG-3' \\
\hline & $\begin{array}{l}\text { Methionine adenosyltransferase }\left(\text { MAT) }{ }^{1} \text { / }\right. \\
\text { XM_799937 }\end{array}$ & $\begin{array}{l}140 \\
b p\end{array}$ & 5'-CTACGCCGTAATGGGACACT-3' & 5'-TGTTGGGCCGAGATAAGAAC-3' \\
\hline & $\begin{array}{l}\text { Dihydrofolate reductase-thymidylate } \\
\text { synthase (DHFR-TS) }{ }^{1} / \text { XM_810234 }\end{array}$ & $\begin{array}{l}164 \\
b p\end{array}$ & 5'-GTGGCGGTAAATGGTGGACT-3' & 5'-ATGGTGGTGCGGTAAATAGC-3' \\
\hline & $\begin{array}{l}\text { Spermidine putrescine transporter }(\text { EPT })^{2} / \\
\text { XM_805310.1 }\end{array}$ & $\begin{array}{l}152 \\
b p\end{array}$ & 5'-TGAATCCACCGTTGCGGGTCT-3' & 5'-CGCATTCTTGACGCTCTGCCT-3' \\
\hline \multirow[t]{5}{*}{$\begin{array}{l}\text { Celullar metabolism } \\
\text { system }\end{array}$} & Histone H1 $(\mathrm{H} 1)^{2} / \mathrm{L} 27119.1$ & $\begin{array}{l}124 \\
b p\end{array}$ & 5'-GCAGCAGCCAAGAAGGCTGT-3' & 5'-CGACAAAGCACGGTTGAGCCA-3' \\
\hline & Zinc finger protein $(Z N)^{2} / X M \_808517$ & $\begin{array}{l}132 \\
b p\end{array}$ & 5'-TGCAGCACGTTCCATTGTGCC-3' & 5'-CGCTGCCGCCCGTAGTTTAAT -3' \\
\hline & $\begin{array}{l}\text { L-threonine dehydrogenase }(\mathrm{TDH})^{2} / \\
\text { XM_807811 }\end{array}$ & $\begin{array}{l}166 \\
b p\end{array}$ & $\begin{array}{c}5^{\prime}- \\
\text { TGAACCCCTCMACGGTKTACGGTGT- } \\
3^{\prime}\end{array}$ & $\begin{array}{c}5^{\prime}- \\
\text { GTACATRTGAATGGCGTAGTCYGTGG- } \\
3^{\prime}\end{array}$ \\
\hline & Glycoprotein gp82 (gp82)/L14824 & $\begin{array}{l}118 \\
b p\end{array}$ & 5'-GCCAACGATAAAGGCAGTGT-3' & 5'-GTGTGGAAGAAGCGGAGAAG-3' \\
\hline & Cruzipain (CZP)²/X54414 & $\begin{array}{l}135 \\
b p\end{array}$ & 5'-CATCGGTGAGGTCCTCTGTT-3' & 5'-CTGTGGTATGGCTGATAGCG-3' \\
\hline
\end{tabular}

1: Genes analyzed for all resistant phenotypes (TCR1x-TCR5x) and the parental sensitive strain

2: Genes analyzed only for the parental sensitive strain and the TCR5x resistant phenotype. 
$1 \mathrm{~h}$. RNA without DNase I treatment was used as a control to test gDNA contamination. After first-strand synthesis, reactions were heat-inactivated at $70^{\circ} \mathrm{C}$ for 20 min and then diluted in nuclease- free water.

\section{Real-time PCR}

The primers used to amplify the selected genes using RT-qPCR were designed by PrimerExpress (Applied Biosystems, Foster City, CA, USA) (Table 1). Reactions were set up in a total volume of $20 \mu \mathrm{l}$ using $5 \mu \mathrm{l}$ of cDNA (diluted 1:100), $10 \mu$ l SYBRGreen I master mix (Qiagen) and $1 \mu \mathrm{M}$ each of gene-specific primer (Table 1 ) and performed in the Rotor-Gene-Q (Qiagen, USA) machine. The cycling conditions were: $95^{\circ} \mathrm{C}$ for $15 \mathrm{~s} ; 45$ cycles of $95^{\circ} \mathrm{C}$ for $15 \mathrm{~s}, 60^{\circ} \mathrm{C}$ for $15 \mathrm{~s}$ and $72^{\circ} \mathrm{C}$ for $15 \mathrm{~s}$ with a single fluorescence measurement; a final elongation step was carried out at $72^{\circ} \mathrm{C}$ for $10 \mathrm{~min}$. Specificity of the PCR products was confirmed by analysis of the dissociation curve. The melting curve program consisted of temperatures between 60 and $95^{\circ} \mathrm{C}$ with a heating rate of $0.1^{\circ} \mathrm{C} / \mathrm{s}$ and a continuous fluorescence measurement. Additionally, the amplicons' expected size and the absence of nonspecific products were confirmed by analysis of the real-time PCR products in 1\% agarose gels in $1 \times \mathrm{TBE}$, stained with ethidium bromide and visualized under UV light.

\section{Analysis of the expression}

As an initial attempt to study mRNA levels, 12 genes were analyzed in the sensitive and resistant phenotypes. Additionally, seven more genes were evaluated for the parental and TcR5x parasites. We also performed a kinetic study of mRNA expression levels for ten genes in the parental population exposed to $50 \mu \mathrm{M} \mathrm{BZ}$ or $0.5 \%(\mathrm{v} / \mathrm{v})$ DMSO. In this assay, mRNA levels were determined for $0,12,24,48$ and $72 \mathrm{~h}$ after exposure to $\mathrm{BZ}$ with the aim of evaluating which genes were up- or down-regulated as a consequence of this treatment. To analyze the differential expressions, the mRNA levels obtained for each gene were compared in every resistant phenotype with respect to the sensitive parental line or with the $0 \mathrm{~h}$ time for the kinetic study. In all cases, we used as a reference the expression of the hypoxanthineguanine phosphoribosyltransferase (HPGRT) gene (Genbank: L07486) and a relative quantification defined with the following formula:

$$
\text { Relative Expression }=\frac{\left(\text { Efficiency }_{\text {target }}\right)^{\Delta \mathrm{CP} \text { target (average of sensitive - average resistant) }}}{\left(\text { Efficiency }_{\text {reference }}\right)^{\Delta \mathrm{CP} \text { reference (average of sensitive - average resistant) }}}
$$

All relative quantification was assessed using REST software 2009, RG mode, using the pair-wise fixed randomization test with 10,000 permutations [30,31], with PCR efficiencies calculated by Rotor-Gene-Q software v.2.02.

\section{Number of gene copies}

The NTR gene amplification and its analyses were done as described previously. The number of gene copies was determined using a relative method [31,32] and using HGPRT as a reference gene that has one copy per haploid genome in T. cruzi [25].

\section{Enzymatic activity assays \\ Total protein extracts}

Fifty milliliters of epimastigote cultures in exponential growth $\left(50 \times 10^{6}\right.$ parasites $\left./ \mathrm{ml}\right)$ were harvested at $855 \mathrm{~g}$ for $10 \mathrm{~min}$ at room temperature. The parasites were washed three times with PBS $1 \times(\mathrm{NaCl} 8 \mathrm{~g} / \mathrm{l}, \mathrm{KCl} 0.2 \mathrm{~g} /$ l, $\mathrm{Na}_{2} \mathrm{HPO}_{4} 1.44 \mathrm{~g} / \mathrm{l}, \mathrm{KH}_{2} \mathrm{PO}_{4} 0.24 \mathrm{~g} / \mathrm{l}, \mathrm{pH} 7.4$ ) and resuspended in a protease inhibitor solution $(2 \mathrm{mM}$ dithiothreitol, $2 \mathrm{mM}$ n-aminocaproic acid, $2 \mathrm{mM}$ EDTA). This was followed by shock temperature lyses for three freezing and thawing cycles. Finally, the lysed cells were centrifuged at 2,380 $\mathrm{g}$ for $20 \mathrm{~min}$ at $4^{\circ} \mathrm{C}$. The integrity of proteins was confirmed using denaturizing gels of (SDS-PAGE) at $10 \%(\mathrm{w} / \mathrm{v})$ and the protein concentration was measured by BCA assay (Pierce, USA).

SOD enzymatic activity was performed as described by Beyer et al. (1986) with slight modifications for a total extract of proteins [33]. We also tested the enzymatic activity for P-450 under the conditions published by Portal et al. (2008) with a minor adjustment [34].

\section{Statistical analysis}

Statistical analyses were performed using the SPSS v.14.0 software package for Windows (SPSS Inc., USA), applying the one-way ANOVA test. Means were compared using the Tukey-Kramer; when the $p$-value was less than 0.05 , the difference was regarded as statistically significant.

\section{Genetic characterization of the BZ-sensitive and BZ- resistant $T$. cruzi populations}

To determine clonal selection or mutation among sensitive and resistant parasites, the genetic variability was evaluated with different molecular markers as follows:

\section{Amplification of $T$. cruzi kDNA 330-bp fragment using PCR}

The variable region of the minicircles of kinetoplast DNA was amplified with the primers 121 (5'-AAATAATGTACGGG(T/G)GAGATGCATGA-3') and 122 (5'-GTTCGATTGGGGTTGGTGTAATATA-3'). PCR was carried out at a final volume of $50 \mu \mathrm{l}$ containing 50 $\mathrm{mM} \mathrm{KCl,} 10 \mathrm{mM}$ Tris- $\mathrm{HCl}, 0.1 \%$ Triton X-100, $25 \mathrm{ng}$ of DNA, 37 pmol of each primer, $200 \mu \mathrm{M}$ of dNTP, 1.5 $\mathrm{mM}$ of $\mathrm{MgCl}_{2}$ and $2.5 \mathrm{U}$ of Taq DNA polymerase. PCR was performed at an initial temperature of $94^{\circ} \mathrm{C}$ for 3 min, followed by 35 cycles at $94^{\circ} \mathrm{C}$ for $45 \mathrm{~s}, 63^{\circ} \mathrm{C}$ for 45 
s, $72^{\circ} \mathrm{C}$ for $45 \mathrm{~s}$ and a final cycle at $72^{\circ} \mathrm{C}$ for $10 \mathrm{~min}$. The amplification products for each sample were analyzed by electrophoresis in $1 \%$ agarose gel in $1 \times \mathrm{TBE}$, stained by ethidium bromide and visualized under UV light.

\section{PCR amplification of the intergenic regions of the of spliced-leader DNA genes (SL DNA)}

PCR amplification was performed in 0.2-ml microcentrifuge tubes containing $25 \mu \mathrm{l}$ of reaction mixture. Primers for amplification of the intergenic region of T. cruzi SL DNA genes were: 5'-GTGTCCGCCACCTCCTTCG GGCC-3' (TC1, group II-specific), 5'-CCTGCAGGCACACGTGTGTGTG-3' (TC2, group I-specific) and 5'CCCCCCTCCCAGGCCACACTG-3' (TC, common to groups I and II). The reaction contained $25 \mathrm{ng}$ of DNA, $50 \mathrm{mM} \mathrm{KCl}, 10 \mathrm{mM}$ Tris- $\mathrm{HCl}$ (pH 8.0), 0.1\% Triton X$100,200 \mu \mathrm{M}$ of each deoxynucleotide triphosphate (dNTP), $1.5 \mathrm{mM} \mathrm{MgCl}_{2}, 12.5 \mathrm{pmol}$ of each primer, and $0.625 \mathrm{U}$ of Taq DNA polymerase. PCR was carried out at an initial temperature of $94^{\circ} \mathrm{C}$ for $3 \mathrm{~min}$, followed by 27 cycles of $94^{\circ} \mathrm{C}$ for $30 \mathrm{~s}, 55^{\circ} \mathrm{C}$ for $30 \mathrm{~s}$, and $72^{\circ} \mathrm{C}$ for $30 \mathrm{~s}$, with a final extension at $72^{\circ} \mathrm{C}$ for $10 \mathrm{~min}$. The amplification products were analyzed by electrophoresis in $1 \%$ agarose gels in $1 \times \mathrm{TBE}$, stained with ethidium bromide and detected by UV light.

\section{LSSP-PCR and RAPDS}

To obtain sequence-specific gene signatures of sensitive and resistant parasites, the LSSP-PCR and RAPDs were used. For LSSP-PCR, both minicircle variable regions (kDNA) and intergenic regions of spliced-leader genes (SL) were used as markers as described by Mejia et al. (2009) [35]. RAPD analysis was achieved using a total of three primers M13-40 (5'-GTTTTCCCAGTCACGAC3'), L15996 (5'-CTCCACCATTAGCACCCAAAGC-3') and lgt11 (5'-GACTCCTGGAGCCCG-3') in four different reactions (all primers together and separately) as described previously by Steindel et al. (1993) [36]. All of the amplification products were analyzed in $3 \%$ agarose gels stained with ethidium bromide and visualized under UV light.

\section{Results}

\section{Induction of in vitro BZ-resistant $T$. cruzi populations}

To investigate the initial mechanisms of BZ response, we used a susceptible Gal $61 \mathrm{~T}$. cruzi as the parental strain and five different phenotypes TcR1x, TcR2x, TcR3x, TcR4x and TcR5 $x$ that were generated by in vitro increasing concentrations of $\mathrm{BZ}$ by a long-term procedure- 25 passages-to reach the maximum concentration of resistance in human plasma $(50 \mu \mathrm{M})$. We then determined the $\mathrm{BZ}$ doses required to inhibit $50 \%$ $\left(\mathrm{IC}_{50}\right)$ for each available population, which ranged from 10.49 to $93.7 \mu \mathrm{M}$ (Figure 1A, Table 2). We also found that the values obtained for the phenotypes from TcR2x to TcR5x were considered to have clearly statistically significant differences in contrast to the parental strain $(p<0.05)$ (Figure 1A). Interestingly, the resistant phenotypes also displayed a cross-resistance to NFX (Figure 1B) but did not show differences when exposed to a non-nitroheterocyclic drug, G418 sulfate (Figure 1C).

\section{Stability of BZ-resistant phenotypes}

T. cruzi-resistant populations from TcR $2 \mathrm{x}$ to TcR5 $\mathrm{x}$ were grown without drug treatment for 3 months (70 generations), then the $\mathrm{IC}_{50}$ was determined to verify that resistant phenotypes were stable. The results did not show a statistically significant difference between the $\mathrm{IC}_{50}$ values for parasite growth in $\mathrm{BZ}$ pressure and those without drug treatment, indicating stability of BZresistant phenotypes over the course of time $(p<0.05)$ (Figure 1A).

\section{Differential gene expression in BZ-resistant phenotypes}

In an initial attempt to identify differential gene expression, 12 genes were selected and their expression level was determined by RT-qPCR (Table 1). In this case, there was not a regular pattern of expression for the resistant TcR1x, TcR2x, TcR3x and TcR4x phenotypes, except for the P450, TS and MDR genes showing a gradual downregulation. However, TcR5x-resistant parasites and the sensitive strain had almost the same expression levels for all the genes evaluated, except by NTR and OYE genes that were found to be downregulated and upregulated, respectively (Figure 2). Given these results, we additionally compared the expression levels of the other seven genes involved in detoxification and other metabolic pathways between sensitive and TcR5x-resistant parasites (Table 1). Similarly, we found no differences between the two phenotypes (data not shown). To analyze the early genetic expression in response to $\mathrm{BZ}$, we tested the mRNA expression levels for ten genes in a sensitive phenotype exposed to $50 \mu \mathrm{M}$ BZ (five times its $\mathrm{IC}_{50}$ ) for different periods of time. The results indicated that there were no significant differences between the different time periods. However, some genes showed different levels of expression, especially the SOD-A gene at 24 $\mathrm{h}$, but then the mRNA levels returned to the same levels of the sensitive strain at $0 \mathrm{~h}$ (without BZ) (Figure 3). Finally, the parasites exposed to DMSO as a control did not show changes in their mRNA levels (data not shown).

\section{Number of gene copies}

OYE and NTR genes were found to play an important role in the therapeutic dose-resistant phenotype TcR5x, possibly decreasing the activation of the pro-drug as a first line of defense. The different regulation of transcripts for NTR and OYE genes could be due to changes 


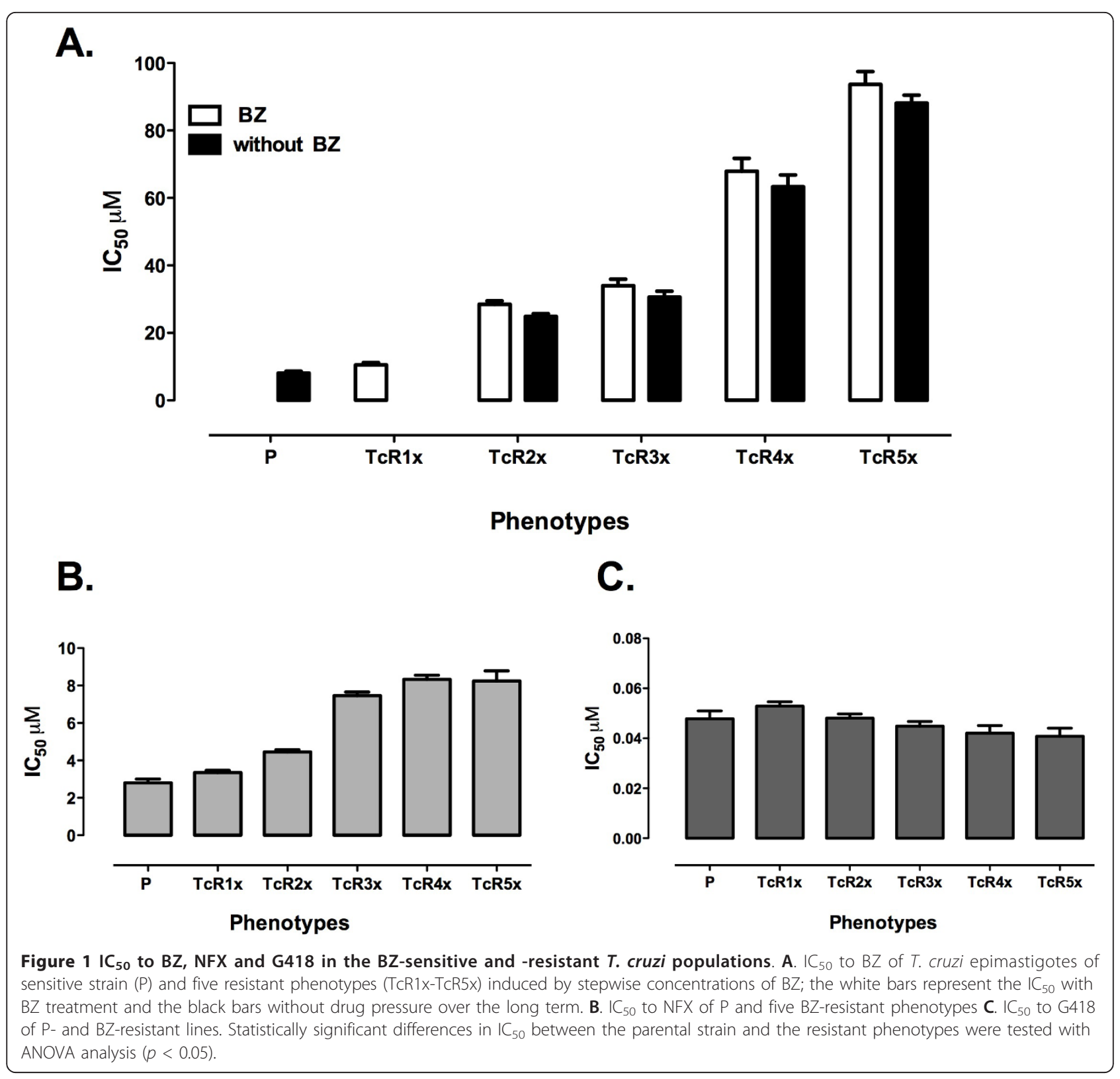

in the number of gene copies. In this manner, this parameter was evaluated by qPCR. The results presented here clearly show that the number of gene copies only differed for NTR in TcR5x BZ-resistant parasites. This gene had two copies per genome diploid in the parental line, but only one was observed in the resistant phenotype (Figure 4). The OYE gene was found to have eight copies in the sensitive phenotype and it was similar for resistant parasites (Figure 4).

\section{Enzymatic activities for SOD and P-450}

Keeping in mind that $\mathrm{P} 450$ is a type II nitroreductase and that SOD enzyme works on detoxification systems once the BZ has been activated, we analyzed both
Table 2 BZ concentration of induction and inhibitory concentration $50 \%$ reached $\left(\mathrm{IC}_{50}\right)$ for resistant phenotypes of Gal61

\begin{tabular}{ccc}
\hline Phenotype & $\begin{array}{c}\text { BZ pressure } \\
(\boldsymbol{\mu M})\end{array}$ & $\begin{array}{c}\mathbf{I C}_{\mathbf{5 0}} \mathbf{B Z} \\
(\boldsymbol{\mu} \mathbf{M})\end{array}$ \\
\hline Gal61 & 0.00 & 9.60 \\
TcR1x & 9.60 & 10.49 \\
TcR2x & 19.20 & 28.50 \\
TcR3x & 28.80 & 33.97 \\
TcR4x & 38.40 & 67.95 \\
TCR5x & 50.00 & 93.70 \\
\hline
\end{tabular}




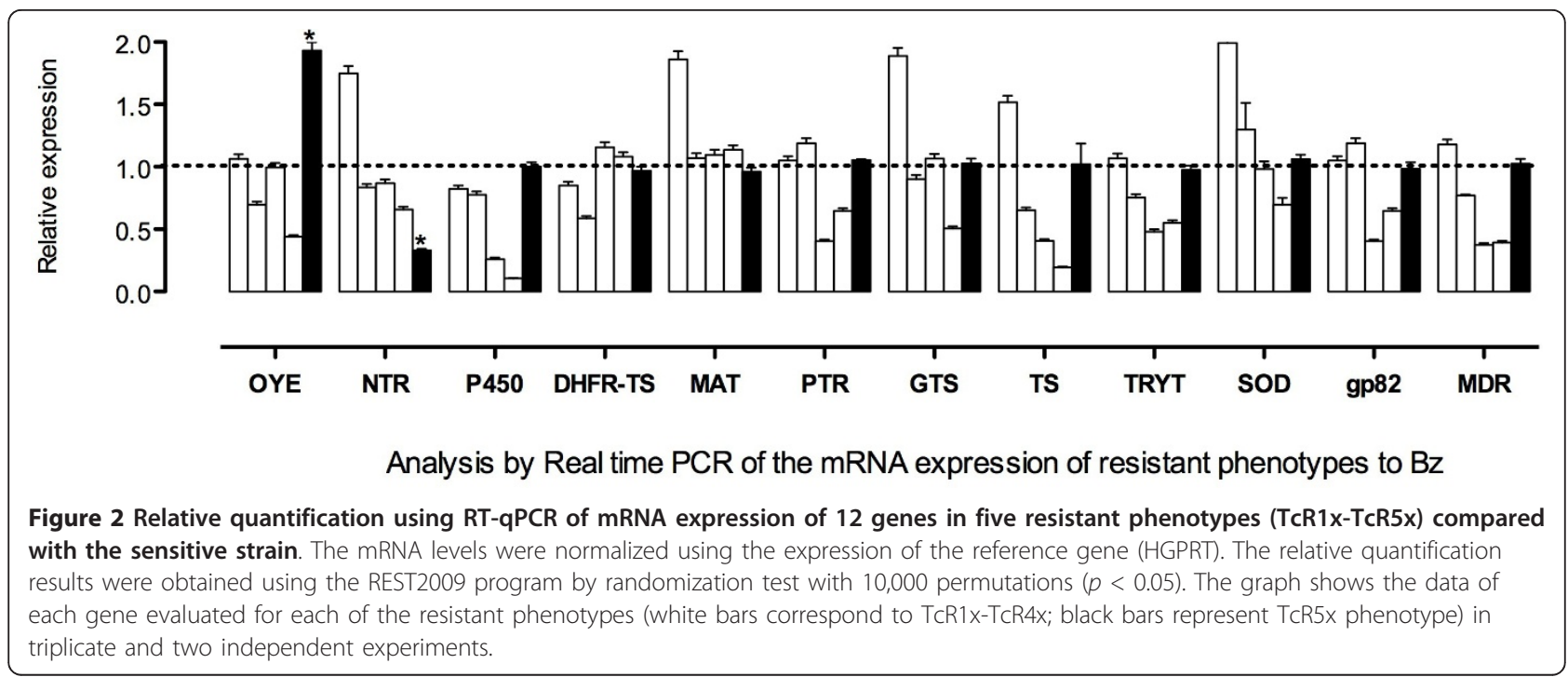

enzymatic activities reported to be implicated in the appearance of $\mathrm{BZ}$ resistance $[26,34]$. We found that these enzymes had similar enzymatic activities between the parental and TcR5x BZ-resistant phenotype. The specific activities of SOD for parental and TcR5x parasites were 18.708 and $18.912 \mathrm{U} / \mathrm{mg}$, respectively, whereas P450 enzymatic activities were $8.1 \times 10 \mathrm{E}-4$ for the parental strain and $8.9 \times 10 \mathrm{E}-4 \mathrm{U} / \mathrm{mg}$ for TcR5x parasites.

\section{Genetic profile of in vitro-induced BZ-resistant} phenotypes

The drug resistance induction procedure could have been generated in the Gal61 strain clonal selection while the resistant phenotypes were being established; for this reason, the genetic profiling of resistant and susceptible parasites was studied. The genetic characterization was carried out by LSSP-PCR of kDNA and SL as well as the RAPD approach. Genetic analyses did not show

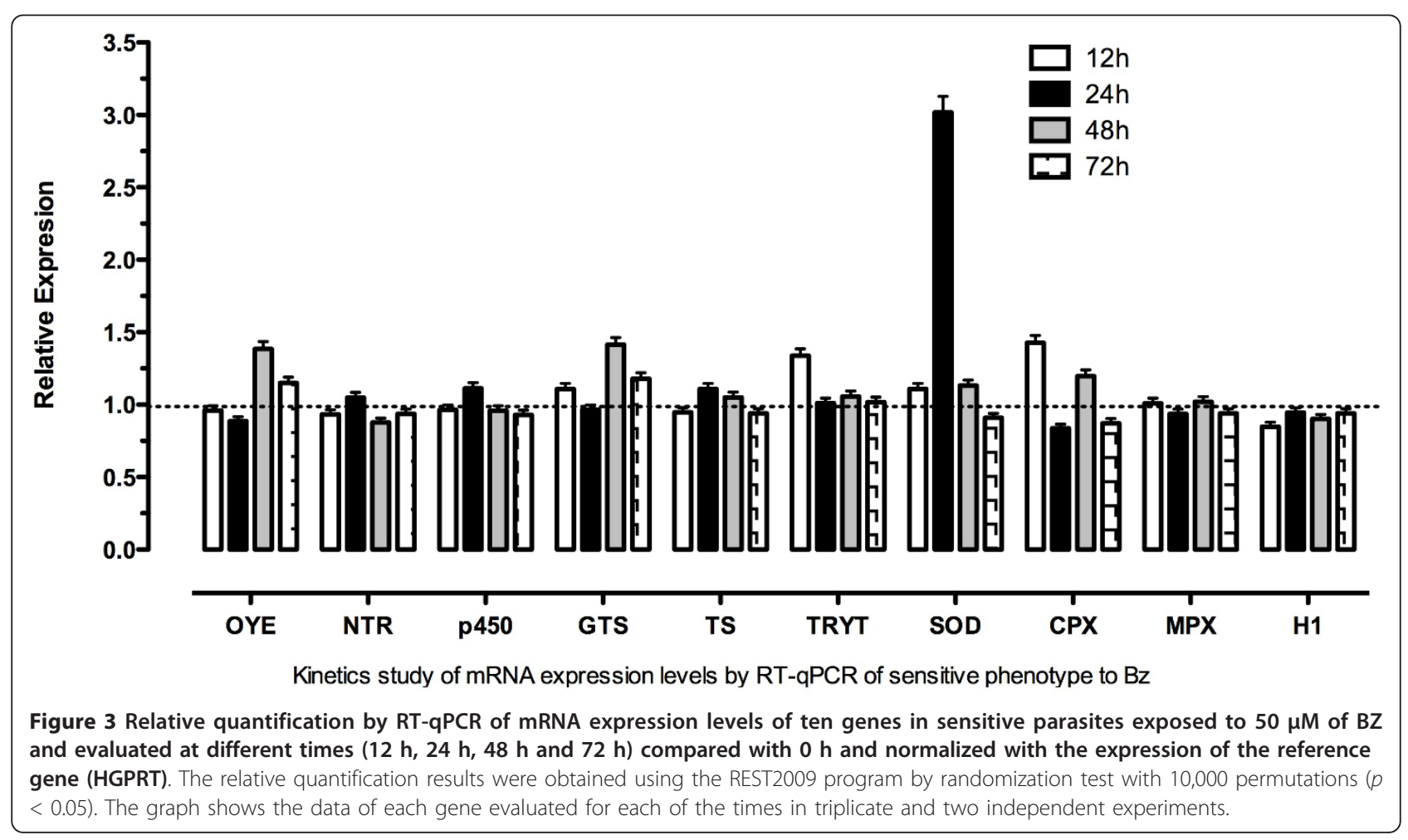




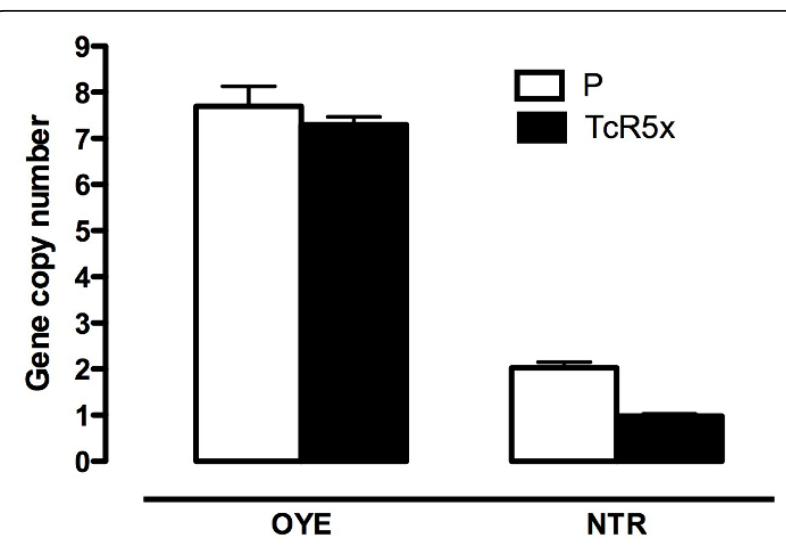

Figure 4 Number of copies of OYE and NTR genes using qPCR for the sensitive parental $(P)$ strain (white bars) and the resistant phenotype TcR5x (black bars). The relative

quantification was normalized using the single copy gene HGPRT.

The results correspond to analyses in duplicate in two independent assays.

evident genetic differences, which indicates a similar genetic background throughout the parasite population (data not shown). Therefore, the results showed that there was no clonal selection or even marked changes of DNA sequences from resistant parasites compared to the parental sensitive line.

\section{Discussion}

Chagas disease is a public health problem in many tropical countries resulting from the lack of effective treatments and vaccines [37]. Two drugs are available to treat the disease, NFX and BZ, which have been previously reported as being impaired treatments with 70\% of patients considered recovered in the acute stage and only $20 \%$ in the chronic stage [37]. Additionally, use of these drugs is usually followed by the appearance of parasite resistance [5]. Consequently, this study focuses on identifying markers of $\mathrm{BZ}$ resistance at different drug concentrations.

In recent years, many studies have been primarily concerned with the development of new treatments [38,39], with a growing tendency toward reports trying to understand how BZ and NFX work within the parasite and less toward the study of early establishment of resistance markers at different drug concentrations. For this reason, we used a high-BZ-sensitivity Gal61 strain originally isolated from a wild reservoir, and we then induced in vitro $\mathrm{BZ}$ resistance by increasing concentrations of BZ. Next, five different resistant populations were established (Table 2, Figure 1A). The BZ response is considered a complex multifactorial trait, which involves many genes of different biochemical pathways because its mode of action is not expected to implicate a specific therapeutic target $[5,6]$. Therefore, this study initially selected 12 genes and later seven more genes for a total of 19 genes, all of which were regarded as potential new markers of BZ-resistance phenotypes.

We found that OYE and NTR were the only two genes that showed differential expression in all the phenotypes including the TcR5x BZ-resistant population (Figure 3). Interestingly, Kubata et al. (2002) found that the OYE enzyme does not metabolize BZ, although it can metabolize naftoquinones and NFX under anaerobic conditions [13]. However, Hall et al. (2011) recently showed that the artificial overexpression of this gene in T. brucei did not induce NFX resistance [12]. Therefore, we believe that increased OYE levels could be a consequence of metabolic changes occurring for the downregulation of the NTR gene without altering the resistance to BZ according to previous reports by Kubata et al. (2002) [13]. Murta et al. (2006) reported the OYE enzyme was associated with $\mathrm{BZ}$ resistance in induced $i n$ vitro $T$. cruzi-resistant lines due to the loss of three of its four gene copies. In this case, these authors associated its function with downstream steps after activation of the drug [25]. Here, we found that the OYE gene was overexpressed in resistant parasites. However, the BZ resistance level reached by the parasites could explain these differences in the transcription profiles found for Murta et al. (2006) and in the present study, where the maximum $\mathrm{IC}_{50}$ obtained was lower $(50 \mu \mathrm{M})$. Recently, Boiani et al. (2010) found that only concentrations higher than $400 \mu \mathrm{M}$ of NFX generated reactive oxygen species (ROS) [40]. Although this generation of ROS by BZ has not been supported by many authors $[6,41]$, it is possible that a high concentration of the drugs has a different mode of action within the parasite, resulting in different biochemical pathways acting on it $[21,26]$.

There have been many nitroreductase enzymes reported in several organisms, such as bacteria and protozoans, that play a role in the activation of a wide spectrum of nitro-compounds such as pro-drugs [42-45]. Members of this protein family from Escherichia coli, Helicobacter pylori and Entamoeba histolytica have shown several alterations such as frameshift mutations, decreased expression, deletions, etc., and these alterations were correlated to nitrofurazone and metronidazole resistance [46-51]. Furthermore, experimental evidence suggests that NTR is the most important enzyme in the activation of NFX, and it is also thought that T. cruzi uses the disruption of this enzymatic catabolism to prevent its therapeutic action through a decreased generation of toxic nitro derivatives [12,15]. Furthermore, a similar observation was made by knockdown silencing through iRNA in T. brucei [52]. Thus, the present results showing the downregulation of NTR are not surprising and are supported by previous 
findings reported by Wilkinson et al. (2008), who proposed that the loss of a single gene copy favors the development of resistance for many heterocyclic compounds in T. cruzi [15]. Recently, it was found that the metabolites generated through reduction of NFX by NTR in T. brucei induce parasite and host cell death; however, if the activation is performed by the host cell it will show no cytotoxic effects [12]. In other words, the loss of cell viability determined only by NTR activation highlights the importance of this enzyme in the mechanism of action of both nitroheterocyclic drugs, BZ as shown here and NFX as reported previously [15].

Surprisingly, the other genes evaluated did not change expression in the TcR5x phenotype, despite regulated changes in expression in the other resistant phenotypes. This could be explained as follows: the decrease of BZ activation caused by the NTR gene losing a copy in the most resistant population could prevent the formation of toxic products that altered expression of enzymes such as TS, P450 and MDR in other phenotypes. This could explain the same levels of expression found for the parental strain and the TcR5x phenotype for at least 17 other genes evaluated.

Approximately 93 genes have been reported to be involved in BZ response with different biological functions such as drug activation, transport, defense of ROS and metabolism, among others [19-23,25,26]. These genes are thought to act in molecular resistance pathways in in vitro-induced parasites, possibly as transitory and/or stable mechanisms to resist and survive the BZtrypanocidal action. However, less than $5 \%$ of these genes have been confirmed in their role in the resistance mechanism and only one, the NTR gene, has been found to be directly involved in the NFX-induced resistance $T$. cruzi $[12,15,52]$. Interestingly, we found the same result in the BZ-induced resistance parasites.

With the aim of detecting genes with an early response to $\mathrm{BZ}$ and determining the possible chemotherapeutic targets of the drug, the levels of mRNA expression of the sensitive phenotype were examined when exposed to $\mathrm{BZ}$ at five times its $\mathrm{IC}_{50}$ for different periods of time. However, a specific profile of expression in the ten genes studied was not found compared to the strain without drugs. In L. amazonensis exposed to arsenic, major changes in the expression of proteins involved in tryparedoxin pathways were detected in the first $7 \mathrm{~h}$ [53]. Therefore, shorter-term assessment may be necessary to detect changes related to the genes involved in detoxification. However, it is possible that other genes that were not studied in this research are affected with relation to other pathways such as heat shock proteins.

Additionally, we investigated the specific activity of two proteins, CPR and SOD. These proteins were chosen because they could participate in the BZ's metabolism role [6], and there is some evidence of their role in resistance to $\mathrm{BZ}[26,34]$. Our results indicate that enzymatic activities for both enzymes were similar among the parental strain and the TcR5x resistant phenotype in accordance with the mRNA level. Thus, recently the overexpression of two different CPRs did not confer resistance to NFX in T. brucei [12]. In conclusion, the level of BZ-resistant phenotypes obtained in this investigation did not support the ROS generation hypothesis.

After the down-regulated expression was found for both NTR and OYE genes, the number of gene copies was calculated using the qPCR approach. The NTR gene had two copies per diploid genome in the parental strain and just one in the TcR5x phenotype as a consequence of the loss of one copy in the acquisition of resistance to BZ, as shown in other studies of NFX conferring resistance to different nitroheterocyclic compounds [15]. These results are in accordance not only with the mRNA expression, but also with previous reports, showing that this technique is capable of detecting changes in the number of copies in an easier and less time-consuming way than other traditional techniques such as Southern blot or pulsed field electrophoresis. For the OYE gene, there were no changes in the number of gene copies, contrary to previous studies that found a loss of three gene copies out of four present in the haploid genome [25]. Therefore, it is also probable that high transcription levels are the result of physiological changes in the resistant parasites and not related to the resistant condition, as discussed above [12].

On the other hand, we found that BZ-resistance parasites presented cross-resistance to NFX (Figure 1B), based upon previous experimental evidence where it was confirmed that resistance could be shared among similar nitroheterocyclic compounds of induced and natural resistance parasites [15,54-56]. However, G418 susceptibility did not show differences within all the phenotypes (Figure 1C). In fact, the molecular mode of action of G418 is different from both NFX and BZ [57]. This means that the resistance or the susceptibility trait shares pathways between both NFX and BZ. Therefore, in the event of clinical resistance, $\mathrm{BZ}$ cannot be changed alternatively for NFX. As a consequence of cross-resistance among nitroheterocyclic compounds, it is necessary to search for promising new compounds.

In addition to our early drug resistance model of $T$. cruzi, we also clearly demonstrate that BZ resistance in these parasitic populations did not necessarily depend on a constant presence of the drug, which can continue over the course of time (Figure 1A). The stability of the resistant phenotype has been confirmed in many in vitro 
and in vivo models through different parasite species $[19,54]$. This condition is the result of many cases of stable genetic alterations such as mutations, amplifications and deletions $[16,18,58]$.

Alves et al. (1994) observed alterations in the restriction fragment length polymorphism of the kDNA in $T$. cruzi submitted to a number of passages during exponential growth phase or after subcloning. This phenomenon was called transkinetoplastid [59] and it consists of fast changes in the kDNA minicircle population leading to different restriction profiles. Thus, LSSP-PCR based on the KDNA variable region can reveal not only changes in the kDNA, but also the profiles of different clones. In this manner, LSSP-PCR and RAPDs analysis have been shown to be good tools in evaluating the genetic variability within the clones belonging to the same strain. These approaches are able to identify multiple or simple variations on the DNA sequence and genetic characterization of $T$. cruzi [35,60-62]. Furthermore, the high variability of kDNA markers has been extensively used to identify many clones within a strain [63]. We induced resistance using a susceptible Gal61 strain as a parental line, which was also genetically stable through different induced BZ-resistant phenotypes using kDNA and SL genes as well as the RAPD approach. Therefore, there was no evidence of clonal selection of resistant parasites or even drastic changes in DNA sequences from resistant parasites compared to the parental sensitive line.

Finally, these results indicate that exposure to BZ leads to early irregular expression of different genes possibly involved in response to cell stress, but the loss of one copy of the NTR gene could be responsible for the acquisition and maintenance of a BZ-resistant line. However, it is necessary to study whether NTR is involved in natural resistance and to use other tools such as next generation sequencing to know whether or not there are other genes affected.

\section{Conclusion}

Diminished mRNA levels of NTR and a loss of one copy of this gene in the BZ-resistant phenotype of T. cruzi were documented. Therefore, we propose that the NTR gene is involved in the emergence of resistance to $\mathrm{BZ}$ and could be used as a reliable marker of resistance in patients treated for T. cruzi infection.

\section{Acknowledgements}

This work was financed by Proyecto 2,599, Banco de la República de Colombia to AMMJ and OTC, Proyecto CPT 09-08 CODI, University of Antioquia to AMMJ, GJF and OTC, and Colciencias Fellowship program to AMMJ, GJF and LP. Thanks are extended to Nathan Hayhoe and Jennifer Peterson for reviewing the English.

\section{Authors' contributions}

Conceived and designed the experiments: AMMJ, GJF, OTC. Performed the experiments: AMMJ, GJF, LP. Analyzed the data: AMMJ, GJF, LP. Wrote the paper: AMMJ, LP, OTC. All authors read and approved the final manuscript.

\section{Competing interests}

The authors declare that they have no competing interests.

Received: 14 June 2011 Accepted: 5 September 2011 Published: 5 September 2011

\section{References}

1. Pinto-Dias J, Schofield C: Social and Medical Aspects: Morbidity and Mortality in General Population. In American Trypanosomiasis Chagas disease: one hundred years of research Edited by: Telleria J, Tibayrenc M , First 2010, 45-54.

2. Patterson J, Guhl F: Geographical Distribution of Chagas Disease. In American Trypanosomiasis Chagas disease: one hundred years of research Edited by: Telleria J, Tibayrenc M , First 2010, 83-114.

3. Coura JR, Castro SLd: A critical review on Chagas disease chemoterapy. Mem Inst Oswaldo Cruz 2002, 97:3-24.

4. Schofield CJ, Kabayo JP: Trypanosomiasis vector control in Africa and Latin America. Parasit Vectors 2008, 1:24.

5. Wilkinson SR, Kelly JM: Trypanocidal drugs: mechanisms, resistance and new targets. Expert Rev Mol Med 2009, 11:e31.

6. Maya JD, Cassels BK, Iturriaga-Vasquez P, Ferreira J, Faundez M, Galanti N, Ferreira A, Morello A: Mode of action of natural and synthetic drugs against Trypanosoma cruzi and their interaction with the mammalian host. Comp Biochem Physiol A Mol Integr Physiol 2007, 146:601-620.

7. Piacenza L, Peluffo G, Alvarez MN, Kelly JM, Wilkinson SR, Radi R: Peroxiredoxins play a major role in protecting Trypanosoma cruzi against macrophage- and endogenously-derived peroxynitrite. Biochem $\lrcorner$ 2008, 410:359-368.

8. Wilkinson SR, Kelly JM: The role of glutathione peroxidases in trypanosomatids. Biol Chem 2003, 384:517-525.

9. Wilkinson SR, Obado SO, Mauricio IL, Kelly JM: Trypanosoma cruzi expresses a plant-like ascorbate-dependent hemoperoxidase localized to the endoplasmic reticulum. Proc Natl Acad Sci USA 2002, 99:13453-13458.

10. Wilkinson SR, Temperton NJ, Mondragon A, Kelly JM: Distinct mitochondrial and cytosolic enzymes mediate trypanothione-dependent peroxide metabolism in Trypanosoma cruzi. J Biol Chem 2000, 275:8220-8225

11. Turrens JF, McCord JM: The iron-containing superoxide dismutases of trypanosomatidae. Free Radic Biol Med 2006, 40:193-195.

12. Hall BS, Bot C, Wilkinson SR: Nifurtimox activation by trypanosomal type I nitroreductases generates cytotoxic nitrile metabolites. J Biol Chem 2011, 286:13088-13095.

13. Kubata BK, Kabututu Z, Nozaki T, Munday CJ, Fukuzumi S, Ohkubo K, Lazarus M, Maruyama T, Martin SK, Duszenko M, Urade Y: A key role for old yellow enzyme in the metabolism of drugs by Trypanosoma cruzi. J Exp Med 2002, 196:1241-1251.

14. Hall $B S$, Wu X, Hu L, Wilkinson SR: Exploiting the drug-activating properties of a novel trypanosomal nitroreductase. Antimicrob Agents Chemother 2010, 54:1193-1199.

15. Wilkinson SR, Taylor MC, Horn D, Kelly JM, Cheeseman I: A mechanism for cross-resistance to nifurtimox and benznidazole in trypanosomes. Proc Natl Acad Sci USA 2008, 105:5022-5027.

16. Ouellette M: Biochemical and molecular mechanisms of drug resistance in parasites. Trop Med Int Health 2001, 6:874-882.

17. Borst $P$, Oullette M: New mechanism of drug resistance in parasitic protozoa. Annu Rev Microbiol 1995, 49:427-460.

18. Hayes JD, Wolf CR: Molecular mechanisms of drug resistance. Biochem J 1990, 272:281-295.

19. Villarreal D, Nirde P, Hide M, Barnabe C, Tibayrenc M: Differential gene expression in benznidazole-resistant Trypanosoma cruzi parasites. Antimicrob Agents Chemother 2005, 49:2701-2709.

20. Campos FM, Liarte DB, Mortara RA, Romanha AJ, Murta SM: Characterization of a gene encoding alcohol dehydrogenase in benznidazole-susceptible and -resistant populations of Trypanosoma cruzi. Acta Trop 2009, 111:56-63. 
21. Nogueira FB, Ruiz JC, Robello C, Romanha AJ, Murta SM: Molecular characterization of cytosolic and mitochondrial tryparedoxin peroxidase in Trypanosoma cruzi populations susceptible and resistant to benznidazole. Parasitol Res 2009, 104:835-844.

22. Andrade HM, Murta SM, Chapeaurouge A, Perales J, Nirdé P, Romanha AJ: Proteomic analysis of Trypanosoma cruzi resistance to Benznidazole. J Proteome Res 2008, 7:2357-2367.

23. Murta SM, Nogueira FB, dos Santos PF, Campos FF, Volpe C, Liarte DB, Nirde P, Probst CM, Krieger MA, Goldenberg S, Romanha AJ: Differential gene expression in Trypanosoma cruzi populations susceptible and resistant to benznidazole. Acta Trop 2008, 107:59-65.

24. Rego JV, Murta SM, Nirde P, Nogueira FB, de Andrade HM, Romanha AJ: Trypanosoma cruzi: characterisation of the gene encoding tyrosine aminotransferase in benznidazole-resistant and susceptible populations. Exp Parasitol 2008, 118:111-117

25. Murta SM, Krieger MA, Montenegro LR, Campos FF, Probst CM, Avila AR, Muto $\mathrm{NH}$, de Oliveira RC, Nunes LR, Nirde P, et al: Deletion of copies of the gene encoding old yellow enzyme (TcOYE), a NAD(P)H flavin oxidoreductase, associates with in vitro-induced benznidazole resistance in Trypanosoma cruzi. Mol Biochem Parasitol 2006, 146:151-162.

26. Nogueira FB, Krieger MA, Nirde P, Goldenberg S, Romanha AJ, Murta SM: Increased expression of iron-containing superoxide dismutase-A (TcFeSOD-A) enzyme in Trypanosoma cruzi population with in vitroinduced resistance to benznidazole. Acta Trop 2006, 100:119-132.

27. Camargo EP: Growth and Differentiation in Trypanosoma cruzi. I. Origin of Metacyclic Trypanosomes in Liquid Media. Rev Inst Med Trop Sao Paulo 1964, 12:93-100.

28. Nirdé $P$, Larroque C, Barnabé C: Drug-resistant epimastigotes of Trypanosoma cruzi and persistence of this phenotype after differentiation into amastigotes. C R Acad Sci Ser 1995, 318:1239-1244.

29. Mosmann T: Rapid colorimetric assay for cellular growth and survival: application to proliferation and cytotoxicity assays. J Immunol Methods 1983, 65:55-63.

30. Pfaffl MW, Horgan GW, Dempfle L: Relative expression software tool (REST) for group-wise comparison and statistical analysis of relative expression results in real-time PCR. Nucleic Acids Res 2002, 30:e36.

31. Pfaffl MW: A new mathematical model for relative quantification in realtime RT-PCR. Nucleic Acids Res 2001, 29:e45.

32. Schneider M, Joncourt F, Sanz J, von Känel T, Gallati S: Detection of exon deletions within an entire gene (CFTR) by relative quantification on the LightCycler. Clin Chem 2006, 52:2005-2012.

33. Beyer WF, Wang Y, Fridovich I: Phosphate inhibition of the copper- and zinc-containing superoxide dismutase: a reexamination. Biochemistry 1986, 25:6084-6088.

34. Portal P, Villamil SF, Alonso GD, De Vas MG, Flawiá MM, Torres HN, Paveto C: Multiple NADPH-cytochrome P450 reductases from Trypanosoma cruzi suggested role on drug resistance. Mol Biochem Parasitol 2008, 160:42-51

35. Mejía-Jaramillo AM, Arboleda-Sánchez S, Rodríguez IB, Cura C, Salazar A, Del Mazo J, Triana-Chávez O, Schijman AG: Geographical clustering of Trypanosoma cruzi I groups from Colombia revealed by low-stringency single specific primer-PCR of the intergenic regions of spliced-leader genes. Parasitol Res 2009, 104:399-410.

36. Steindel $M$, Dias Neto $E_{\text {, }}$ de Menezes $C L$, Romanha AJ, Simpson AJ: Random amplified polymorphic DNA analysis of Trypanosoma cruzi strains. Mol Biochem Parasitol 1993, 60:71-79.

37. Rodrigues J, Castro S: A Critical Review on Chagas Disease Chemotherapy. Mem Inst Oswaldo Cruz 2002, 97:3-24.

38. Buckner FS, Navabi N: Advances in Chagas disease drug development: 2009-2010. Curr Opin Infect Dis 2010, 23:609-616.

39. Urbina JA: Specific chemotherapy of Chagas disease: relevance, current limitations and new approaches. Acta Trop 2010, 115:55-68.

40. Boiani M, Piacenza L, Hernández P, Boiani L, Cerecetto H, González M, Denicola A: Mode of action of nifurtimox and N-oxide-containing heterocycles against Trypanosoma cruzi: is oxidative stress involved? Biochem Pharmacol 2010, 79:1736-1745.

41. Maya JD, Bollo S, Nuñez-Vergara LJ, Squella JA, Repetto Y, Morello A, Périé J, Chauvière G: Trypanosoma cruzi: effect and mode of action of nitroimidazole and nitrofuran derivatives. Biochem Pharmacol 2003, 65:999-1006.
42. McCalla DR, Reuvers A, Kaiser C: "Activation" of nitrofurazone in anima tissues. Biochem Pharmacol 1971, 20:3532-3537.

43. Aiub CA, Mazzei JL, Pinto LF, Felzenszwalb I: Evaluation of nitroreductase and acetyltransferase participation in $\mathrm{N}$-nitrosodiethylamine genotoxicity. Chem Biol Interact 2006, 161:146-154.

44. Searle PF, Chen MJ, Hu L, Race PR, Lovering AL, Grove Jl, Guise C, Jaberipour M, James ND, Mautner $V$, et al: Nitroreductase: a prodrugactivating enzyme for cancer gene therapy. Clin Exp Pharmacol Physiol 2004, 31:811-816.

45. Race PR, Lovering AL, Green RM, Ossor A, White SA, Searle PF, Wrighton CJ, Hyde El: Structural and mechanistic studies of Escherichia coli nitroreductase with the antibiotic nitrofurazone. Reversed binding orientations in different redox states of the enzyme. J Biol Chem 2005, 280:13256-13264.

46. McCalla DR, Kaiser C, Green MH: Genetics of nitrofurazone resistance in Escherichia coli. J Bacteriol 1978, 133:10-16.

47. Whiteway J, Koziarz P, Veall J, Sandhu N, Kumar P, Hoecher B, Lambert IB: Oxygen-insensitive nitroreductases: analysis of the roles of nfsA and $\mathrm{nfs} B$ in development of resistance to 5-nitrofuran derivatives in Escherichia coli. J Bacteriol 1998, 180:5529-5539.

48. Wassmann C, Hellberg A, Tannich E, Bruchhaus I: Metronidazole resistance in the protozoan parasite Entamoeba histolytica is associated with increased expression of iron-containing superoxide dismutase and peroxiredoxin and decreased expression of ferredoxin 1 and flavin reductase. J Biol Chem 1999, 274:26051-26056.

49. Kwon DH, Osato MS, Graham DY, El-Zaatari FA: Quantitative RT-PCR analysis of multiple genes encoding putative metronidazole nitroreductases from Helicobacter pylori. Int J Antimicrob Agents 2000, 15:31-36.

50. Kwon DH, Peña JA, Osato MS, Fox JG, Graham DY, Versalovic J: Frameshift mutations in rdxA and metronidazole resistance in North American Helicobacter pylori isolates. J Antimicrob Chemother 2000, 46:793-796.

51. Kwon DH, Kato M, El-Zaatari FA, Osato MS, Graham DY: Frame-shift mutations in $\mathrm{NAD}(\mathrm{P}) \mathrm{H}$ flavin oxidoreductase encoding gene (frxA) from metronidazole resistant Helicobacter pylori ATCC43504 and its involvement in metronidazole resistance. FEMS Microbiol Lett 2000, 188:197-202

52. Baker N, Alsford S, Horn D: Genome-wide RNAi screens in African trypanosomes identify the nifurtimox activator NTR and the eflornithine transporter AAT6. Mol Biochem Parasitol 2011, 176:55-57.

53. Hsu JY, Lin YC, Chiang SC, Lee ST: Divergence of trypanothionedependent tryparedoxin cascade into cytosolic and mitochondrial pathways in arsenite-resistant variants of Leishmania amazonensis. Mol Biochem Parasitol 2008, 157:193-204.

54. Buckner FS, Wilson AJ, White TC, Van Voorhis WC: Induction of resistance to azole drugs in Trypanosoma cruzi. Antimicrob Agents Chemother 1998, 42:3245-3250.

55. Prathalingham SR, Wilkinson SR, Horn D, Kelly JM: Deletion of the Trypanosoma brucei superoxide dismutase gene sodb1 increases sensitivity to nifurtimox and benznidazole. Antimicrob Agents Chemother 2007, 51:755-758.

56. Kelly J, Taylor M, Smith K, Hunter K, Fairlamb A: Phenotype of recombinant Leishmania donovani and Trypanosoma cruzi which over-express trypanothione reductase. Sensitivity towards agents that are thought to induceoxidative stress. Eur J Biochem 1993, 218:9.

57. Eustice DC, Wilhelm JM: Mechanisms of action of aminoglycoside antibiotics in eucaryotic protein synthesis. Antimicrob Agents Chemother 1984, 26:53-60.

58. Singh N: Drug resistance mechanisms in clinical isolates of Leishmania donovani. Indian J Med Res 2006, 123:411-422.

59. Alves A, Almeida Dd, Von Kruger W: Changes in Trypanosoma cruzi kinetoplast DNA minicircles induced by environmental conditions and subcloning. J Euk Microbiol 1994, 41:415-419.

60. Mejia AM, Triana O: Genetic variability of Trypanosoma cruzi in blood and organs of infected mice determined by LSSP-PCR. Biomedica 2005, 25:76-86.

61. Vago AR, Macedo AM, Oliveira RP, Andrade LO, Chiari E, Galvao LM, Reis D, Pereira ME, Simpson AJ, Tostes S, Pena SD: Kinetoplast DNA signatures of Trypanosoma cruzi strains obtained directly from infected tissues. Am J Pathol 1996, 149:2153-2159. 
62. Vago AR, Andrade LO, Leite AA, d'Avila Reis D, Macedo AM, Adad SJ, Tostes S Jr, Moreira MC, Filho GB, Pena SD: Genetic characterization of Trypanosoma cruzi directly from tissues of patients with chronic Chagas disease: differential distribution of genetic types into diverse organs. Am J Pathol 2000, 156:1805-1809.

63. Pacheco RS, Brito CM: Reflections on the population dynamics of Trypanosoma cruzi: heterogeneity versus plasticity. Mem Inst Oswaldo Cruz 1999, 94(Suppl 1):199-201.

doi:10.1186/1756-3305-4-169

Cite this article as: Mejía-Jaramillo et al:: Gene expression study using real-time PCR identifies an NTR gene as a major marker of resistance to benznidazole in Trypanosoma cruzi. Parasites \& Vectors 2011 4:169.

Submit your next manuscript to BioMed Central and take full advantage of:

- Convenient online submission

- Thorough peer review

- No space constraints or color figure charges

- Immediate publication on acceptance

- Inclusion in PubMed, CAS, Scopus and Google Scholar

- Research which is freely available for redistribution

Submit your manuscript at www.biomedcentral.com/submit 